\title{
Chapter 3 \\ Innovations for Food and Nutrition Security: Impacts and Trends
}

\author{
Evita Pangaribowo and Nicolas Gerber
}

\begin{abstract}
Achieving food and nutrition security (FNS) is a priority in developing countries. One of the key routes to achieve a resilient global food system and improved FNS requires a reorientation of relevant policies. Among them, policies associated with the creation, adoption and adaptation of technologies, knowledge and innovations and with their related institutional adjustments are key factors to counter the complex and evolving challenges of the global food system. In line with this notion, the objectives of this chapter are severalfold. First, we discuss the main features of innovations for FNS. Second, we describe the impact of innovations on FNS using the examples of new platform and traditional technology. Third, this chapter elaborates on the views of a variety of stakeholders concerning the impacts of technological and institutional innovations, as well as the future priorities of FNS innovation.
\end{abstract}

Keywords Food and nutrition security • Food system • Resilience • Innovations • Policies

\section{Introduction}

According the UN Secretary-General Ban Ki-moon, food and nutrition security (FNS) are the foundations of a decent life. ${ }^{1}$ The UN Universal Declaration of Human Rights stated that "everyone has the rights to a standard of living adequate for the health and well-being of himself and his family, including food" and mandated food as a human right. One of the key routes to achieve a resilient global

\footnotetext{
${ }^{1}$ http://www.un.org/waterforlifedecade/food_security.shtml.

E. Pangaribowo $(\bowtie)$

Department of Environmental Geography, University of Gadjah Mada, Yogyakarta, Indonesia e-mail: evitahp@ugm.ac.id

N. Gerber

Center for Development Research (ZEF), University of Bonn, Walter Flex Strasse 3,

53113 Bonn, Germany

e-mail: ngerber@uni-bonn.de
}

(C) The Author(s) 2016

F.W. Gatzweiler, J. von Braun (eds.), Technological and Institutional Innovations for Marginalized Smallholders in Agricultural Development, DOI 10.1007/978-3-319-25718-1_3 
food system and improved FNS requires a reorientation of relevant policies. Among them, policies associated with the creation, adoption and adaptation (a process called diffusion) of technologies, knowledge and innovations and with their related institutional adjustments (Juma and Yee-Cheong 2005) are key factors for countering the complex and evolving challenges of the global food system.

FNS worldwide is currently in an alarming state, despite global progress towards the achievement of Millennium Development Goal number 1. The steep rise in food prices in 2007-2008 and the volatility of food prices in the following period have negatively impacted the poor in particular, and some studies have shown an important reduction in calorie intake and an increase in poverty rates in general (Webb 2010). It is recognized that the overall impact of the high food prices on welfare depends on the status of the target groups or the time horizon of the analysis (e.g., net food buyers versus sellers, short term versus long term impacts) (Swinnen 2011). Notwithstanding, the episode of high and volatile food prices of 2007-2008 has definitely slowed down progress in terms of decreased malnutrition (von Braun and Tadesse 2012) and hampered achievements in the fight against food insecurity. Further, many countries (mostly of low middle income) are currently experiencing a triple burden of under- or malnutrition: undernourishment, overnourishment and hidden hunger. Undernourishment, or hunger, is effectively the insufficient intake of energy and proteins, which has been directly linked to diseases and premature death, as well as poor physical development. The UNICEF framework of undernutrition (Black et al. 2008) laid out how the lack of household access to and use of nutritious foods, health care, water and sanitation services are among the major drivers of undernutrition. Overnourishment is the excessive intake of dietary energy, resulting in overweight, obesity and chronic diseases, as well as with increasing risks of non communicable diseases (NCD). Overnourishment is driven by many factors, including the globalization of trade, finance, change of information and cultures, change of lifestyles and physical activity patterns, and demographic shifts - in particular, urbanization (Hawkes et al. 2005; Popkin et al. 2012). The third burden, hidden hunger, is a situation when people suffer from micronutrient deficiency. The major driver of micronutrient deficiencies is lack of access to and consumption of nutrient dense foods such as fruit and vegetables. In the low and middle income countries, people are mostly suffering from iron, zinc, vitamin A, iodine and folate deficiency (Muthayya et al. 2013). Iron deficiency is one of the leading causes of maternal mortality. Particularly for children, the triple burden of malnutrition has devastating effects on later life, including physical and cognitive development. Under- and overnourishment cannot coexist in the same individual, but can be observed in the same household. Micronutrient deficiency can coexist with under- or overnourishment in an individual and in a household.

The chapter primarily aims to discuss the main features of innovations for FNS, as well as present their impact pathways. A consultation with several stakeholders of the food (innovation) system about the impacts of innovations on FNS, now and in the future, illustrates the plurality of views about the necessity to invest in different types of innovations for FNS, thus helping to identify priorities for action in the field of FNS and innovation. This consultation suggests that, although 
technological innovation is important for increasing agricultural production, institutional factors such as farmers' collective action should be well supported in directing future science policy for agriculture and FNS. Understanding the impacts of innovations on FNS and the priorities for innovation in the future requires better knowledge on the current state of FNS, which is discussed in the next section.

\section{Current FNS Situation}

FAO reported last year that, in the period of 2011-2013, around one in eight people in the world were estimated to be suffering from chronic hunger, a situation where people do not have enough food to perform an active life (FAO et al. 2013). Even though this figure was slightly improved compared to the previous period, substantial efforts are needed to meet the Sustainable Development Goal No. 2 of ending hunger by 2013. The efforts should account for regional differences, although globally, Sub-Saharan Africa and South Asia still rank highest as the homes of malnourishment (Fig. 3.1 ${ }^{2}$ ). As we can see from Fig. 3.1, Sub-Saharan Africa and South Asia have the highest prevalence of stunting among children under-five, both at $38 \%$. The consequences of stunting for later life are enormous. Victora et al. (2008) pointed out that stunted children were associated with low human capital and higher risk of adult diseases. Apart from stunting, underweight is also more prevalent in South Asia and Sub-Saharan Africa than in other parts of the world, at a rate of $33 \%$ and $21 \%$, respectively. The consequences of underweight are also severe. Empirical studies show that being underweight in childhood was positively associated with low adult body-mass index, intellectual performance and work capacity (Martorell 1999; Victora et al. 2008). For wasting, it is also evident that the situation in South Asia is alarming. In that region, around one in six children is suffering from wasting. Wasting indicates current or acute malnutrition and children suffering from wasting have a higher mortality risk.

Recent studies revealed that many developing countries have experienced a multiple burden of malnutrition where undernutrition (mainly stunting) and overnutrition (overweight and obesity) coexist in the same population or household (Hawkes et al. 2005; FAO 2006). UNICEF reported that $7 \%$ of children under-five were overweight in 2012, and this number represents a $43 \%$ increase from 1990. Overnutrition is becoming an alarming signal in developing countries, as obesity and diet-related chronic diseases are increasing in developing countries

\footnotetext{
${ }^{2}$ Stunting refers to the proportion of children aged under-five falling below minus 2 standard deviations (moderate and severe) from the median height-for-age of the WHO growth standard. Underweight refers to the proportion of children aged under-five falling below minus 2 standard deviations (moderate and severe) from the median weight-for-age of the WHO growth standard. Wasting refers to the proportion of children aged under-five falling below minus 2 standard deviations (moderate and severe) from the median weight-for-height of the WHO growth standard. Overweight refers to the proportion of children aged under-five falling above 2 standard deviations from the median weight-for-height of the WHO growth standard.
} 


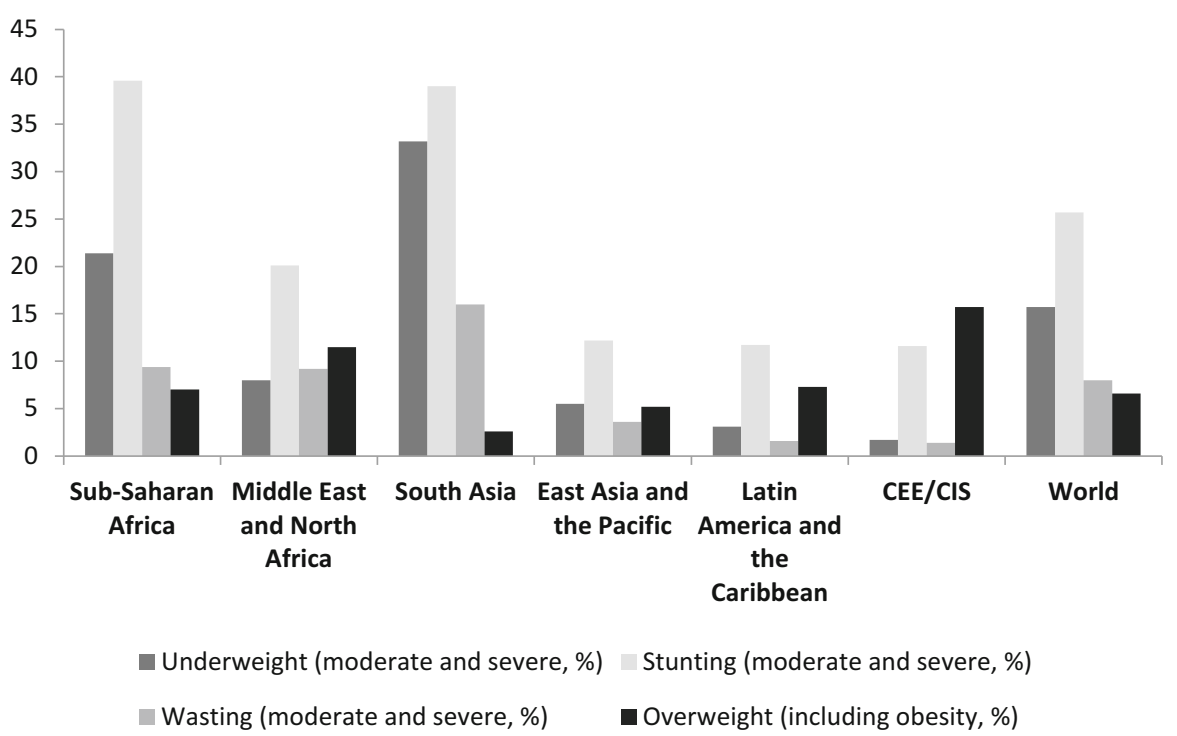

Fig. 3.1 Global Nutritional Status, 2012 (Source: Childinfo.org, UNICEF)

(Shetty 2012). Optimizing the window of opportunities for preventing undernutrition and overnutrition from pre-pregnancy to the first 1000 days of life is strongly needed. Gómez et al. (2013) add another burden, the so-called micronutrient malnutrition or 'hidden hunger', which owes its name to the fact that the symptoms of the problems are not always visible. Hidden hunger is a condition in which people suffer from a chronic deficiency of micronutrients or essential vitamins and minerals. Currently, it is estimated that two billion people suffer from chronic deficiency of micronutrients. India, Afghanistan and many countries of Sub-Saharan Africa have an alarming situation of micronutrient deficiency where iron, vitamin A, and deficiency are highly prevalent in school children (Muthayya et al. 2013). Table 3.1 presents the countries most affected by multiple micronutrient deficiencies, several of them being high on the list of countries with high prevalence of under- and overnutrition. Micronutrient deficiency has huge consequences for later life. A study by Lozoff et al. (2013) shows that a chronic iron deficiency is associated with lower level of educational attainment (not completing secondary school and not pursuing further education/training). Chronic iron deficiency is also associated with poorer emotional health and more negative emotions in later life. Muthayya et al. (2013) estimated that micronutrient deficiencies contribute to $1.5-12 \%$ of the total Disability Adjusted Life Years (DALY).

Despite those above challenges the world is facing nowadays, we should be hopeful about the future. Innovations and FNS-related policies are among the potential ways to address those problems. The rest of the chapter discusses the trend and impact of innovations in reducing malnutrition and enhancing FNS. 
Table 3.1 Top 20 countries affected by hidden hunger

\begin{tabular}{|c|c|c|c|c|c|}
\hline \multirow[b]{2}{*}{ Rank } & \multirow[b]{2}{*}{ Country } & \multirow[b]{2}{*}{$\begin{array}{l}\text { Hidden hunger index } \\
\text { score }\end{array}$} & \multicolumn{3}{|c|}{$\begin{array}{l}\text { Deficiency prevalence } \\
(\%)\end{array}$} \\
\hline & & & Zinc & Iron & $\begin{array}{l}\text { Vitamin } \\
\text { A }\end{array}$ \\
\hline 1 & Niger & 52.0 & 47.0 & 41.8 & 67.0 \\
\hline 2 & Kenya & 51.7 & 35.8 & 34.5 & 84.4 \\
\hline 3 & Benin & 51.3 & 44.7 & 39.1 & 70.7 \\
\hline 4 & Central African Republic & 51.0 & 43.0 & 42.1 & 68.2 \\
\hline 5 & Mozambique & 51.0 & 47.0 & 37.4 & 68.8 \\
\hline 6 & Sierra Leone & 50.0 & 37.4 & 37.9 & 74.8 \\
\hline 7 & Malawi & 49.7 & 53.2 & 36.6 & 59.2 \\
\hline 8 & India & 48.3 & 47.9 & 34.7 & 62.0 \\
\hline 9 & Burkina Faso & 48.3 & 44.5 & 45.8 & 54.3 \\
\hline 10 & Ghana & 47.7 & 28.6 & 39.0 & 75.8 \\
\hline 11 & São Tomé and Príncipe & 47.7 & 29.3 & 18.4 & 95.6 \\
\hline 12 & Afghanistan & 47.7 & 59.3 & 19.0 & 64.5 \\
\hline 13 & $\begin{array}{l}\text { Democratic Republic of the } \\
\text { Congo }\end{array}$ & 47.7 & 45.8 & 35.7 & 95.6 \\
\hline 14 & Mali & 46.0 & 38.5 & 40.7 & 58.6 \\
\hline 15 & Liberia & 45.3 & 39.4 & 43.4 & 52.9 \\
\hline 16 & Côte d'Ivoire & 44.0 & 40.1 & 34.5 & 57.3 \\
\hline 17 & Gambia & 43.7 & 27.6 & 39.7 & 64.0 \\
\hline 18 & Chad & 43.3 & 44.8 & 35.6 & 50.1 \\
\hline 19 & Madagascar & 43.0 & 52.8 & 34.2 & 42.1 \\
\hline 20 & Zambia & 42.0 & 45.8 & 26.5 & 54.1 \\
\hline
\end{tabular}

Source: http://reliefweb.int/sites/reliefweb.int/files/resources/Hidden_Hunger_Index_Executive_ Summary.pdf. The Hidden Hunger Index is the average, for preschool children, of three deficiency prevalence estimates: stunting (as a proxy for zinc deficiency, as recommended by the International Zinc Nutrition Consultative Group), iron-deficiency anemia and vitamin A deficiency. The three components were equally weighted (Hidden Hunger score $=[$ stunting $(\%)+$ anemia $(\%)+$ low serum retinol $(\%)] / 3$ )

\section{The Main Features of Technological and Institutional Innovations for FNS}

It is argued that both 'hardware' and 'software' are needed for societies to develop and ultimately to prosper (Woodhill 2010). According to Woodhill (2010), 'hardware' refers to technological innovations while 'software' represents institutional innovation and arrangements. Along with this notion, this chapter classifies innovations for FNS into two main types: technological and institutional innovations. The features of technological innovations are closely related to the sources of technology. Following Conway and Waage (2010), the sources of technology are categorized as conventional, traditional, intermediate and new platforms for technology. 
"Conventional technologies" are produced by industrialized countries through the application of modern knowhow in physics, chemistry, and biology. They are available in regional or global markets as a packaged form. The conventional technologies were normally developed in the form of agricultural inputs, such as fertilizer, high yielding varieties and irrigation tools, globally known as the tools of the Green Revolution. The original aim of conventional technological innovations is to diffuse knowledge to farmers to increase agricultural production through the transfer of knowledge embedded in the products (Dockes et al. 2011).

Traditional technologies are defined as technologies which have been developed by the local communities to meet their local needs. This type of innovation is derived from the traditional practices, generally shaped over a period of time by communities in developing countries and proven to be effective as complements to conventional technologies. Several traditional technologies, particularly agricultural systems, have been promoted and recognized globally. As a traditional technology is invented and adopted by local people, this technology is also referred to as indigenous technical knowledge (Conway and Waage 2010). In the farming system, a traditional technology is characterized by a low use of inputs, reflecting the (lack of) opportunities available to smallholder farmers (Meyer 2010). A (controversial) example of farming practice rooted in age-old agricultural practices is the system of rice intensification (SRI). SRI has been widely adopted globally in the last decade beyond its country of origin, Madagascar (Uphoff and Kassam 2008).

Intermediate technologies are a mix between conventional and traditional technologies (Conway and Waage 2010). The application of such technologies is supported by an institutional change so that they can provide a full range of benefits to small farmers. As examples, Polak et al. (2003) listed three types of affordable small-plot irrigation systems which developed from the mix of conventional and traditional technologies, including the treadle pump, low cost drip irrigation, and the low cost sprinkler system. These low-cost irrigation technologies enable poor farmers to have access to water and, at the same time, to reduce production costs. The treadle pump is one of the successful intermediate technologies, developed in Bangladesh during the 1980s (Namara et al. 2010). The objective of the treadle pump development was threefold: a high and sustainable agricultural output, low cost technology, and simplicity of production, installation and use. In support, a variety of mass marketing actions were implemented in the 1980s by an international non-profit organization, International Development Enterprises (IDE) (Hierli and Polak 2000; Namara et al. 2010). Currently, the treadle pump has been adopted across Africa and Asia (Kay and Brabben 2000).

The new platform technologies applied in fostering FNS include information and communication technologies (ICT) for the agricultural sector, biotechnology, and nanotechnology. ICT have been widely applied for enhancing better market access, as well as empowering local farmer organizations. Many risks and uncertainties normally faced by smallholder farmers before, during and after production can be overcome via mobile phone information, accordingly boosting their production. The mobile phone services are on several fronts, ranging from providing market and price information to knowledge sharing, insuring crop production to monitoring 
children's nutrition status. In the application of biotechnology, biofortification is among the most cost-effective ways of improving nutritional outcomes.

Institutional innovations involve social and political processes in which the actors of innovation contribute to a larger action by combining inherited practices, technologies and institutions to address their interest (Hargrave and van De Ven 2006). Institutions are defined as the rules of society or organizations that support the people or members by helping them form and deal with their expectations about each other so that they achieve common objectives (Ruttan and Hayami 1984; World Bank 2002). As mentioned earlier, innovation is a process involving various institutional arrangements and inter-agent coordination. In the FNS-related areas, more specifically in the agricultural sector, institutional innovations have emerged in the form of the coordination of actions and interests of farmers, markets, and policymakers. As mentioned above, the downsides of the Green Revolution are mainly due to the related social policies, not to the technologies themselves. Therefore, institutional innovation plays a substantial role in accompanying technological innovation and making it beneficial for the people.

One of the innovative institutions related to FNS are the Farmer Field Schools (FFS) (Braun et al. 2006). Originated in Indonesia, FFS have long been recognized as an initiative to address the challenge of pest management and the heterogeneous ecological aspects of farming activities. Nevertheless, FFS have also been implemented in other fields, such as resource management (Nepal), adoption of agricultural technologies (Kenya), and diffusion of knowledge (Mexico). Despite the small budgets needed to sustain the FFS, a great number of international and national NGOs have been involved thoroughly in FFS since the early 1990s. A good practice in FFS is the involvement of FFS alumni in Indonesia and the Philippines as full-time FFS facilitators. Apart from pest management and farming practices, the FFS alumni were also trained with new skills, such as computer and entrepreneurial development (Braun et al. 2006; Braun and Duveskog 2008).

IFAD (2007) outlines the importance of institutional innovations in facilitating access to natural resources and local governance, access to productive assets and markets, access to information and knowledge, and increasing political capital. The World Development Report 2008 on Agriculture for Development (World Bank 2008) documents several focus areas of institutional innovations, including new mechanisms to increase land tenure security for smallholder farmers, financial and services access, risk mitigation and management, as well as efficient input markets.

\section{The Impacts of Innovations}

This chapter features two types of technology, including new platform and traditional technology, as well as institutional innovations and their contribution to the enhancement of FNS. The new platform technology is now the focus of policies, as this type of technology has profound long-term implications, particularly in the context of FNS. The spikes in food and energy prices in 2007-2008 have triggered 
the increase in input costs which negatively affected the supply responses from the producer side. Thus, the introduction of the new platform technologies in the agricultural sector plays a role for both producers and consumers. In the more globalized market, the new platform technologies benefit producers and consumers in their involvement in the supply chain through better access to market information. With the challenge of climate variability, new platform technologies offer small-holder farmers tools for decision-making, including on what and when to grow. In addition, traditional technology often contributes to improving agricultural technology. Low income farmers have limited access to modern technology, thus traditional technologies benefit them most, as they are most accessible and affordable. This chapter also provides an overview as to how the institutional innovations through community-based innovation impact FNS.

Analyzing the impacts of innovations on FNS cannot be separated from the FNS dimensions: availability, accessibility, utilization and stability. Following Masset et al. (2012) and Webb (2013), the impact of innovation and agricultural interventions are channeled through multiple pathways, both direct and indirect. The indirect pathway is chiefly linked to the accessibility dimension, while the direct pathways are associated with the availability dimension of FNS. While the indirect pathway goes through income, the direct pathways are channeled through food production and improved food quality, more diverse diet composition, food prices, non-food spending, and intrahousehold resource allocation. The latter can be impacted through three channels: women's control over resources; women's time and caring practices; and improved women's nutrition and health. It is recognized that the pathways through intrahousehold resource allocation are still poorly explored, particularly innovations that target the three channels altogether (Webb 2013). Our chapter focuses on several types of innovation, including the new platform technology through ICT and biofortification, traditional technology exemplified here by home gardens, and institution innovation through community-based actions. The first new platform technologies through ICT and biofortification are chosen, as these two technologies are projected to be among the priority of public investment in agricultural knowledge systems (IAASTD 2009). On the other hand, traditional technology is sometimes overlooked in term of its contribution to FNS. This chapter highlights the long contribution of traditional technology through home gardens that have been providing households with rich and diversified diets. In terms of institutional innovation through community-based institutions, this chapter outlines the impact of institutional arrangement in facilitating smallholder farmers to increase their voice and have better access to markets and services. We focus on FFS as one of the most established institutional innovations.

\section{The Impact of New Platform Technology}

The new platform technologies applied in fostering FNS include information and communication technologies (ICT) for the agricultural sector, biotechnology, and 
nanotechnology. This chapter focuses on two new platform technologies: ICT and biofortification. ICT have been widely applied for enhancing better market access, as well as empowering local farmer organizations. In the application of biotechnology, food fortification is among the most cost-effective ways to improve nutritional outcomes.

\section{ICT}

ICT cover technologies used to handle information and communication, including internet, radio, television, video, digital cameras, and other hardware and software. In the former era, ICT in developing countries mainly served as an entertaining gizmo and a means of communication. The modern application of ICT has provided more services through most areas of development, including agriculture, education and health. The mushrooming of ICT applications in many developing countries provides an opportunity to transfer knowledge through the private and public information systems (Aker 2011). One of the ICT applications is the widespread and varied use of mobile phones. Over the past decade, mobile phone subscriptions have increased considerably in developing countries (ITU 2011). The greatest benefits of mobile phones are the significantly reduced communication and information costs, geographic coverage and the convenient use of the technology (Aker and Mbiti 2010). As more and more people, particularly the poor, have enjoyed the benefits of mobile phones, a number of innovators in developing countries have taken the opportunity to use it in various aspects of local life (Conway and Waage 2010). Since early 2007, there have been a number of applications through mobile phones for farming, health, banking, and advocacy.

The impact pathways of ICT on FNS are mainly through improved agricultural production and access to market-related information, which accordingly increases farmers' income. ICT support farmers by improving agricultural productivities through information on the precise input use and environmentally-friendly agricultural production. One notable example of the role of ICT in agricultural production is through software for plant nutrient application rate. Pampolino et al. (2012) found that the use of Nutrient Expert for Hybrid Maize (NEHM) software increased the yield and economic benefits of farmers in Indonesia and the Philippines through the provision of information on nutrient application rate. For farming activities, the expanding use of mobile phones supports farmers' access to information on agricultural extension services, markets, financial services and livelihood support (Donner 2009), translating to better access to extension services, better market links and distribution networks, and better access to finance (World Bank 2011). Ultimately, the mobile phone applications for farmers will improve farmers' income, lower transaction and distribution costs for input suppliers, improve traceability and quality standards for buyers, and create new opportunities for financial institutions. In more detail, Aker (2011) highlights the significance of mobile phones for agricultural services adoption and extension in developing countries 
through improved access to private information, farmer's management of input and output supply chains, facilitation of the delivery of other services, increased accountability of extension services, and increased communication linkages with research systems. The perspective of the private sector (Vodafone Group and Accenture 2011) also emphasizes the potential solution offered by mobile applications in improving data visibility for supply chain efficiency. Based on the review of 92 mobile applications for agriculture and rural develpoment, Qiang et al. (2011) found that the major service provided by the application is information provision. It is also found that only a few of the applications are already sustainable, while $33 \%$ of them are at the concept proof stage and $55 \%$ are at the scaling-up phase.

Along the agricultural chain, the introduction of the new platform technologies in the agricultural sector through ICT plays a significant role for both producers and consumers. In developing countries, most smallholder farmers act as producers and consumers at the same time, and ICT offer a unique opportunity for rural farmers to access market information, weather, and extension services. Several empirical studies reveal that ICT have a significant impact both on producer and consumer welfare (Jensen 2007). Arguably, there are several potential channels for ICT to affect accessibility: by increasing farmer's profitability, and thus income, ICT can enable a farmer to improve consumption, whilst at the same time enabling them to save and accumulate resources. Labonne and Chase (2009) assessed the positive impact of ICT on per capita consumption. In India, Reuters Market Light (RML) provides services in terms of agricultural information dissemination over mobile phones. However, Fafchamps and Minten (2012) found that RML had a small effect on crop grading and no significant impact on prices received by farmers. There is also no significant difference in crop losses resulting from rainstorms. Fafchamps and Minten (2012) argued that a small number of subscribers and slow take-up rate might play a part as the underlying factor. Another study in India found that internet kiosks and warehouses supplied through the e-Choupal program reduced the price dispersion, thus benefiting both producers and consumers (Goyal 2010).

\section{Biofortification}

In the area of FNS, biotechnology plays a supportive role through tissue culture in the quest for more effective and beneficial traits and genetic engineering technology. Genetic engineering has been used widely but has mostly concentrated on increasing resistance to environmental stresses, pests, and diseases. However, recent developments in biotechnology have moved in another direction: high yield crops and more nutritious crops and animal products. In order to bring some of these benefits to the poor, who typically lack access to nutritious foods, such as fruits, vegetables, and animal source foods (fish, meat, eggs, and dairy products) and rely heavily on staple foods, there is a need for staple-related biotechnology.

One of the new platform technologies in this area is biofortification, a process of introducing nutrients into staple foods. Biofortification can be conducted through 
conventional plant breeding, agronomic practices such as the application of fertilizers to increase zinc and selenium content, or transgenetic techniques (Bouis et al. 2011). The smallholder farmers cultivate a large variety of food crops developed by national agricultural research centers with the support of the Consultative Group on International Agricultural Research (CGIAR). One of the global initiatives for biofortification is known as HarvestPlus. ${ }^{3}$ Biofortification provides a large outreach, as it is accessible to the malnourished rural population which is less exposed to the fortified food in markets and supplementation programs. By design, biofortification initially targets the more remote population in the country and is expanded later to urban populations. To be successful, i.e., to improve people's absorption and assimilation of micronutrients, biofortification should meet several challenges, some of which require additional accompanying interventions: successful breeding in terms of high yields and profitability, making sure nutrients of biofortified staple foods are preserved during processing and cooking, the degree of adoption and acceptance by farmers and consumers, and the coverage rate (the proportion of biofortified staples in production and consumption) (Nestel et al. 2006; Meenakshi et al. 2010; Bouis et al. 2011). The development of biofortification is outlined in Table 3.2. In the case of food processing, Meenakshi et al. (2010) estimated that the greatest processing losses are in the case of cassava in Africa, where the loss of vitamin A during the cooking process is between $70 \%$ and $90 \%$. For other staple crops such as sweet potato and rice, the processing loss can be anticipated, as both staple foods are consumed in boiled form.

Biofortification has been implemented in several countries of Asia and Africa (Table 3.3). A number of crops are biofortified, including rice, wheat, maize, cassava, pearl millet, beans, and sweet potato, depending on the national context. Biofortification is found to be cost-effective in terms of the moderate breeding costs, which amount to approximately $0.2 \%$ of the global vitamin A supplementation (Beyer 2010), while the benefit is far higher than the cost. ${ }^{4}$ Compared with other types of interventions, such as supplementation and food fortification, biofortification seems more cost-effective..$^{5}$ Nevertheless, biofortification is not without its limitations, as it might not be viable for application in all plants. For instance, from a breeding perspective, the breeding system of some plants is very complex (Beyer 2010). In Uganda, banana is the primrary staple food, accounting for a per capita per year consumption of nearly $200 \mathrm{~kg}$. However, the vitamin and

\footnotetext{
${ }^{3}$ HarvestPlus is a part of the CGIAR research program on Agriculture for Nutrition and Health under the coordination of the International Center for Tropical Agriculture (CIAT) and the International Food Policy Research Institute (IFPRI).

${ }^{4}$ See the detail example in Bouis et al. (2011).

${ }^{5}$ HarvestPlus provides an example as to how much $\$ 75$ million (US) is worth for supplementation, fortification and biofortification, respectively. That amount of money could buy vitamin A supplementation for 1 year for 37.5 million pre-school children in the South Asian countries of Bangladesh, India and Pakistan; likewise, it could be used for iron fortification for 1 year for 365 million persons, accounting for $30 \%$ of the population in Bangladesh, India, and Pakistan. Contrastingly, the same amount could finance the cost of developing and disseminating iron and zinc fortified rice and wheat for all of South Asia, a crop which would continue to thrive year after year.
} 
Table 3.2 HarvestPlus pathway to impact

\begin{tabular}{l|l}
\hline Stage & Activity \\
\hline \multirow{2}{*}{ Discovery } & Identifying target populations and staple food consumption profiles \\
\cline { 2 - 2 } & Setting nutrient target levels \\
\cline { 2 - 2 } & Screening and applying biotechnology \\
\hline Development & Crop improvement \\
\cline { 2 - 2 } & Gene by environment (GxE) interactions on nutrient density \\
\cline { 2 - 2 } & Nutrient retention and bioavailability \\
\cline { 2 - 2 } & Nutritional efficacy studies in human subjects \\
\hline Delivery & Releasing biofortified crops \\
\hline & Facilitating dissemination, marketing, and consumer acceptance \\
\hline & Improved nutritional status of target populations \\
\hline
\end{tabular}

Source: Bouis et al. (2011)

Table 3.3 Target crops, nutrients, countries, and release dates

\begin{tabular}{l|l|l|l}
\hline Crop & Nutrient & Country & Year of release \\
\hline Bean & Iron & DR Congo, Rwanda & 2012 \\
\hline Cassava & Vitamin A & DR Congo, Nigeria & 2011 \\
\hline Maize & Vitamin A & Nigeria, Zambia & 2012 \\
\hline Pearl millet & Iron & India & 2012 \\
\hline Rice & Zinc & Bangladesh, India & 2013 \\
\hline Sweet potato & Vitamin A & Mozambique, Uganda & 2007 \\
\hline Wheat & Zinc & India, Pakistan & 2013 \\
\hline
\end{tabular}

Source: http://www.harvestplus.org/content/crops

mineral content of the banana is very low. Producing bananas fortified with micronutrients is challenging, as the conventional breeding of a banana is less viable and takes more processing. Another limitation of biofortification is the fact that the potential benefits of biofortified staple foods are uneven across staple food groups, as the need of micronutrients varies along the lifecycle of the crop (Bouis et al. 2011).

\section{The Impact of Traditional Technology Through the Home Garden}

Traditional technologies are defined as technologies which have been developed by the local communities to meet their local needs. This type of innovation is derived from traditional practices, generally shaped over a period of time by communities in developing countries and proven to be effective as complements to conventional technologies. Several traditional technologies, particularly agricultural systems, have been promoted and recognized globally. As a traditional technology is invented and adopted by local people, this technology is also referred to as indigenous technical knowledge (Conway and Waage 2010). In the farming system, 
a traditional technology is characterized by low use of inputs, reflecting the (lack of) opportunities available to smallholder farmers (Meyer 2010). A (controversial) example of a farming practice rooted in age-old agricultural practices is the system of rice intensification (SRI). SRI has been widely adopted globally in the last decade beyond its country of origin, Madagascar (Uphoff and Kassam 2008).

Another example of traditional technology globally applied are home gardens. Home gardens represent a traditional agricultural practice that has been applied mostly in rural areas, acting as food buffer stock for smallholders. Apart from that, home gardens provide more benefits, including wealth generation, bargaining power in labor markets, post-harvest storage, non-agricultural income generating activities, and access to credit (Hanstad et al. 2002). It should be noted that the traditional technology of the home garden is also considered to be a viable and effective way to improve micro-nutrient consumption. Vegetables and fruits are both important sources of vitamins and minerals. Some vegetables, including wellknown types such as tomato (Solanum lycopersicum), cabbage (Brassica oleracea), and onions (Allium cepa), as well as traditional local vegetables, such as moringa (Moringa oleifera), kangkong (Ipomoea aquatic), perilla (Perilla frutescens), anemone (Nymphoides hydrophylla), bitter gourd (Momordica charantia) and jute mallow (Corchorus olitorius), are available in most Southeast Asian countries and are normally grown in home gardens (Table 3.4). Those traditional vegetables are rich in micronutrients. For example, tomato contains more $\beta$-carotene, vitamin $\mathrm{E}$ and iron but has lower antioxidant activity compared to cabbage (Yang and Keding 2009). However, compared to commercially-available tomatoes, even moringa can have 38 times the amount of $\beta$-carotene, 24 times the amount of vitamin $\mathrm{C}$, and 17 times the amounts of vitamin E, folates and iron (Hughes and Keatinge 2011).

Recently, home gardening has been used as a sustainable strategy that can address multiple micronutrient deficiencies through dietary diversification (Cabalda et al. 2011). At the same time, home gardens also serve as an integrated agro-ecosystem (Soemarwoto et al. 1985; Kehlenbeck et al. 2007; Galluzzi et al. 2010). In Java, ${ }^{6}$ home gardens (pekarangan) are well-developed and characterized with great diversity relative to their $\operatorname{size}^{7}$ (Soemarwoto et al. 1975, 1985). The structure of home gardens in Java varies from place to place, ranging from 80 to 179 plant species (Soemarwoto et al. 1985). More importantly, Javanese home gardens contribute primarily to vitamin A and C provision, $12.4 \%$ and $23.6 \%$, respectively, of the recommended dietary allowance (Arifin et al. 2012), and to $20 \%$ of household income (Stoler 1978). In Cambodia and Nepal, 31-65\%, respectively, of household income is derived from revenue from sale of poultry raised in the home garden (Mitchell and Hanstad 2004). In the Philippines, a study found that having a home garden is positively associated with diversity in the children's diet and the frequency of vegetable consumption (Cabalda et al. 2011).

\footnotetext{
${ }^{6} \mathrm{Java}$ is one of the principal islands and the most densely populated in Indonesia.

${ }^{7}$ The size of pekarangan normally takes at least $120 \mathrm{~m}^{2}$ (Arifin et al. 2012) or covers $10-15 \%$ of the cultivatable area (Mitchell and Hanstad 2004).
} 
Table 3.4 Nutritional contents per $100 \mathrm{~g}$ of selected staples, traditional fruits and vegetables in Southeast Asian Home Garden Households

\begin{tabular}{|c|c|c|c|c|c|}
\hline Crop & $\begin{array}{l}\text { Protein } \\
(\mathrm{g})\end{array}$ & $\begin{array}{l}\text { Vitamin A } \\
(\mathrm{mg})\end{array}$ & $\begin{array}{l}\text { Vitamin C } \\
(\mathrm{mg})\end{array}$ & $\begin{array}{l}\text { Calcium } \\
(\mathrm{mg})\end{array}$ & Iron (mg) \\
\hline Wheat & 11.6 & 0 & 0 & 68 & 2.8 \\
\hline $\begin{array}{l}\text { Rice (white, polished, } \\
\text { cooked) }\end{array}$ & 2.2 & 0 & 0 & 7 & 0.4 \\
\hline Rice (white, polished, raw) & 6.8 & 0 & 0 & 19 & 1.2 \\
\hline $\begin{array}{l}\text { Pearl millet, combined vari- } \\
\text { eties, raw }\end{array}$ & 5.7 & 0 & 1 & 18 & 13.1 \\
\hline Custard apple & $1.17-2.47$ & $0.007-0.0018$ & $15-44.4$ & $17.6-27$ & $0.42-1.14$ \\
\hline Mangosteen & $0.5-0.6$ & $\mathrm{n} / \mathrm{a}$ & $1-2$ & $0.01-8$ & $0.2-0.8$ \\
\hline Persimmon & 0.7 & $\mathrm{n} / \mathrm{a}$ & 11 & 6 & 0.3 \\
\hline Wax apple & $0.5-0.7$ & $0.003-0.008$ & $6.5-17$ & $5.6-5.9$ & $0.2-0.82$ \\
\hline Jackfruit (pulp) & $1.3-1.9$ & $\mathrm{n} / \mathrm{a}$ & $8-10$ & 22 & 0.5 \\
\hline Rambutan & 0.46 & & 30 & 10.6 & \\
\hline Durian & $2.5-2.8$ & 0.018 & $23.9-25$ & $7.9-9$ & $0.73-1$ \\
\hline Moringa (leaves) & 8.6 & 19.7 & 274 & 584 & 10.7 \\
\hline Okra (fruit) & 1.8 & 0.4 & 37 & 44 & 0.9 \\
\hline Kangkong (leaves) & 2.4 & 0.4 & 40 & 220 & 2.5 \\
\hline Common cabbage & 1.7 & 0.4 & 49 & 52 & 0.7 \\
\hline Mungbean (grain) & 23.8 & 0.02 & 15 & 55 & 2.8 \\
\hline Tomato & 0.9 & 0.2 & 30 & 9 & 0.6 \\
\hline Sweet pepper & 4.4 & 2.5 & 93 & 188 & 2.1 \\
\hline $\begin{array}{l}\text { Bird's nest fern (Asplenium } \\
\text { australasicum) }\end{array}$ & 2.8 & $\mathrm{n} / \mathrm{a}$ & Very high & Low & Low \\
\hline $\begin{array}{l}\text { Anemone (Nymphoides } \\
\text { hydrophylla) }\end{array}$ & 0.7 & Medium & Low & Low & Low \\
\hline $\begin{array}{l}\text { Sesbania (Sesbania grandi- } \\
\text { flora) leaves }\end{array}$ & 8 & Very high & Very high & High & Very high \\
\hline $\begin{array}{l}\text { Chinese cedar (Toona } \\
\text { sinensis) }\end{array}$ & $6.3-9.8$ & Medium & Very high & High & High \\
\hline
\end{tabular}

Source: Hughes and Keatinge (2011), compiled from Australian Custard Apple Growers Association (ACAGA) (2011), Lim (1996), Morton (1987), Yang and Keding (2009), Lin et al. (2009), Institute of Nutrition, Mahidol University (2014), Stadlmayr et al. (2010)

Children from households with a home garden are more likely to consume more vitamin A (vegetables) and have a more diverse diet.

\section{Future Trends and Priorities of FNS Innovation: A Stakeholder Survey}

The stakeholder survey aims to collect a range of opinions, stakeholder attitudes and understandings of the impacts of innovations on FNS, as well as of the tradeoffs of innovations in terms of FNS, socio-economic or environmental impacts. The 
results provide general directions that can be used in building scenarios for FNS innovations and their impacts in the future, based on the inferred likelihood of innovation creation and development, as well as adoption. The questionnaire is designed as a simple, non-technical survey in order to appeal to respondents with various educational and professional backgrounds. The number of respondents is 42 , and the survey was constructed to approach a limited number of stakeholders with a key interest in FNS, agriculture and natural resources. The professional background of the respondents is fairly diverse: almost $40 \%$ of the respondents work with NGOs, $25 \%$ are from the public sector and academia, $17.1 \%$ are from international agencies (i.e., FAO), $7.3 \%$ are from the private sector, $7.3 \%$ are farmers and the rest are from the general public. The survey was conducted online in February 2013.

\section{General FNS Awareness}

The first part of the survey assesses the general awareness of the respondents to FNS issues. The respondents were asked whether they had previously heard the term 'food and nutrition security' (FNS), what FNS means, and to list five priorities (multiple choice) for improving FNS. The majority of the respondents (almost $95 \%$ ) were aware of the expression "FNS". This high percentage is not surprising, as almost a quarter of the respondents report FNS as their field of expertise. However, it is interesting to see how the respondents defined FNS. The survey provided a closed question with six definitions, namely:

- everyone has enough food,

- stable food supply in the future,

- all food is safe to eat,

- well-functioning food distribution,

- consumption of high quality of food, and

- ensuring consumption of healthy food through hygienic cooking preparation.

Ninety percent of the respondents chose 'everyone has enough food' and 'stable food supply in the future'. Around $78 \%$ of the respondents indicated that FNS should encompass the consumption of quality food (i.e., micronutrients, calorific content). The stakeholders' perception of FNS is paralleled by The United Nations High Level Task Force on Global Food Security (HLTF) through their Comprehensive Framework for Action (CFA). The framework defines food and nutrition security as a condition in which all people, at all times, have physical, social and economic access to sufficient, safe, and nutritious food which meets their dietary needs and food preferences for an active and healthy life.

To understand the future priorities of FNS innovations, respondents were prompted with a list of types of innovation and asked to choose five of them. The most common answers are as follows (\% of respondents): 
- promoting a sustainable and diversified agricultural sector (71.8\%),

- improving farmer's skill $(69.2 \%)$,

- empowering farmers through collective action (53.8\%),

- income generating programs $(51.3 \%)$, and

- increasing agricultural crop production (46.2\%).

This result suggests that, although technological innovation is important for increasing agricultural production, institutional factors through farmer's collective action should be given more emphasis in directing future science policy for agriculture and FNS.

We also asked respondents to rank the relevance of the FNS dimensions, availability, accessibility, utilization and stability, in the context of developing countries and how the relevance of these dimensions may change with time. Around $80 \%$ of the respondents agreed that accessibility in the present and in the future is highly relevant for developing countries. Almost $70 \%$ of the respondents reported that utilization, both in the present and in the future, is highly relevant for developing countries. It is interesting that the availability dimension was seen as less relevant. In comparison, about $58 \%$ of the respondents stated that availability in the present and in the future is highly relevant for developing countries. Thus, stakeholders consider that the future FNS innovations should go beyond the availability dimension, as FNS problems in developing countries are more complex. Many developing countries are entrenched with a dual, sometime triple burden of malnutrition, where undernutrition and overnutrition (overweight and obesity) coexist in the same population or household (Hawkes et al. 2005; FAO 2006), often compounded by a deficiency in micronutrients. Overnutrition in particular is mainly a result of a change in information and culture, and a change in lifestyles and physical activity patterns, as well as of the globalization of trade and finance (Hawkes et al. 2005; Popkin et al. 2012). Tackling these drivers of obesity may indeed require more innovations of the institutional type than presently exist.

\section{Agricultural Innovations and FNS}

We prompted respondents with a list of agricultural innovations (generic or specific). ${ }^{8}$ First, the respondents were asked about their familiarity with the type of innovation provided in the survey. Among the innovations, FFS was the most familiar to the respondents $(75 \%)$, followed by local farmer organization empowerment $(67 \%)$, and farmer extension services (52\%). The respondents assessed GM

\footnotetext{
${ }^{8}$ The list of innovation included ICT, farmer extension services, FFS, empowering local farmer organization, rural micro-finance schemes, supply chain management, animal breeding programs, new/modern seed varieties, adapted inputs for small scale farming, food fortification programs, new/integrated water management, and GM crops.
} 
crops as the least relevant technological innovation for FNS in developing countries. The results are affected by and, indeed, are consistent with the stated future priorities for innovations (Fig. A1, Appendix). Our survey also asked respondents to rank the innovations according to their environmental friendliness. FFS was seen as the most likely to be environmentally friendly (80\%), followed by new/integrated water management $(77 \%)$, empowering local farmer organizations and farmer extension services (both at $46 \%$ ). Around $40 \%$ of the respondents reported that adapted inputs for small scale farming and GM crops are likely to have a negative impact on the environment (Fig. A2, Appendix).

Perceptions of the economic sustainability of innovations was also queried. While around $71 \%$ of the respondents saw that FFS is economically sustainable, they were more likely to state that empowering local farmer organization is the most economically sustainable innovation for FNS. Similarly, this type of innovation is seen by the respondents (almost $70 \%$ ) as the most widely applicable beyond the original/experimental setting (Fig. A3, Appendix). The issue of trade-offs between the FNS, environmental, social, and/or economic impacts of innovations was also examined. The respondents rated institutional innovations such as FFS and local farmer organization (55\% and 50\%, respectively) as the most likely to have trade-offs. On the other hand, ICT, supply chain management, and food fortification ( $30 \%, 30 \%$, and $20 \%$, respectively) were seen as the least likely to have trade-offs between environmental, social, and/or economic aspects (Fig. A4, Appendix). Finally, respondents were asked (closed question) about the two main barriers to the adoption of innovation. For all types of innovations, respondents stated that limited farmer's access and lack of education and training are the two main barriers to adoption (Fig. A5, Appendix).

\section{Conclusions}

FNS continues to be an important challenge in developing countries. Volatile food prices have had mixed effects, but overall have slowed down the progress of achieving FNS. Even though many low middle income countries are now reducing hunger, they are currently experiencing a triple burden of malnutrition, experiencing undernutrition, overnutrition and 'hidden hunger' at the same time. Furthermore, it is estimated that two billion of the world's population suffer from hidden hunger, a chronic deficiency of essential micronutrients. To address these problems, a strong performance in FNS-related sectors, including agriculture and health, is urgently required. In addition to that, policies associated with the diffusion of technologies, knowledge and innovations, as well as institutional arrangements, are key factors in countering the complex and evolving challenges of FNS-related problems. 
This study aims to review the role of technological and institutional innovation in FNS-related areas, discuss the main features of innovations for FNS, and describe the impact of innovation on FNS using the examples of new platform and traditional technology. Innovations have contributed to countering the challenges to FNS from the drivers of hunger and poverty, such as rising population, environmental pressures and price fluctuations. In many developing countries, where the small-holder farmers are the main target group, many factors hindering the achievement of FNS are related to the increasing demand for and lack of access to food.

Drawing from two types of technologies, innovations impact FNS through multiple pathways, directly and indirectly. The direct pathways perform through improved food production, which might lead to improved food quality through more diverse diet composition. However, FNS innovations should not only emphasize the supply side or the accessibility of food, but also focus on alleviating "hidden hunger". Our analysis shows that new-platform technologies can be directed at improvements in nutrition outcomes for the whole population and for the poorest. Biofortification provides opportunities to smallholder farmers to access and grow more nutritious food crops with rich micronutrient content. In addition, traditional technology through home gardens has proven to be an effective way to enhance the quality of nutritionally deficient diets through the locally grown vegetables and fruits of smallholder farmers.

Finally, the stakeholder survey pointed out that innovations for FNS should address various challenges, including climate change and environmental issues, energy and water availability, globalization of trade, finance, change in lifestyles and physical activity patterns, and demographic shifts. Based on the results of the stakeholder survey, appropriate 'software' through innovative institutions is recognized by several stakeholder groups as one of the most viable and effective FNS innovations. The survey also raised concerns about the role of institutional innovation in enabling developing countries to achieve FNS with lower environmental impacts. In a situation in which the agricultural sector routinely encounters new challenges and uncertainties, it is critical to refine the farming systems to increase resource use efficiency. Therefore, the new technologies for agricultural production should focus on precision farming, new crop varieties that have better nutritional quality, and diversified traditional crop systems for high-value horticulture.

Open Access This chapter is distributed under the terms of the Creative Commons AttributionNoncommercial 2.5 License (http://creativecommons.org/licenses/by-nc/2.5/) which permits any noncommercial use, distribution, and reproduction in any medium, provided the original author(s) and source are credited.

The images or other third party material in this chapter are included in the work's Creative Commons license, unless indicated otherwise in the credit line; if such material is not included in the work's Creative Commons license and the respective action is not permitted by statutory regulation, users will need to obtain permission from the license holder to duplicate, adapt or reproduce the material. 


\section{Appendix}

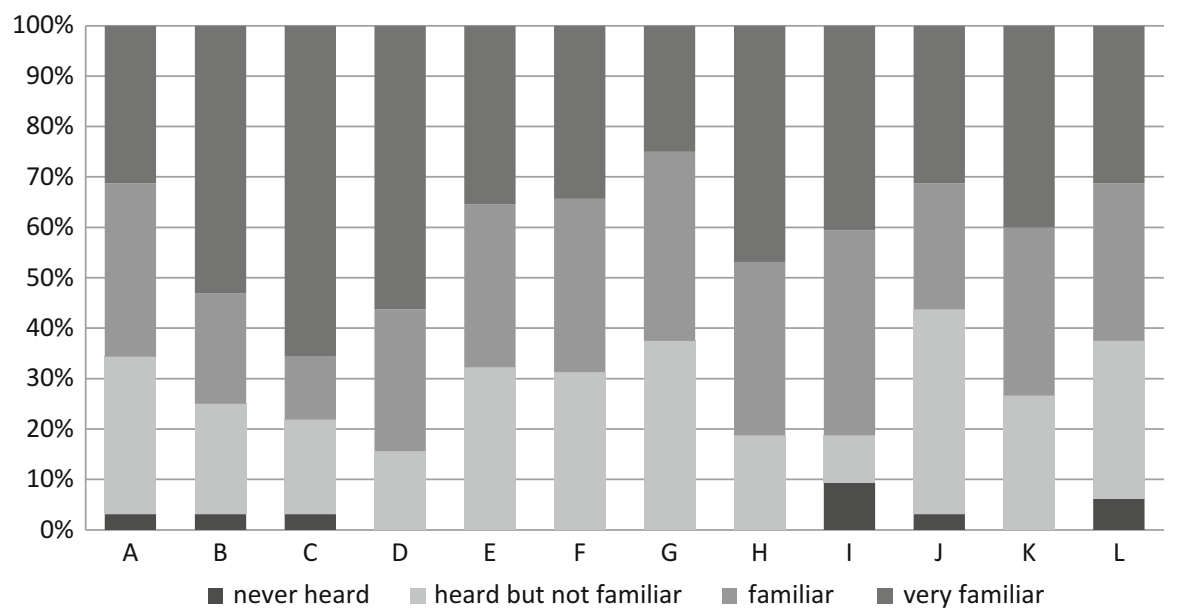

Fig. A1 How familiar are you with the following agricultural types of innovation? (Source: Authors' compilation based on survey)

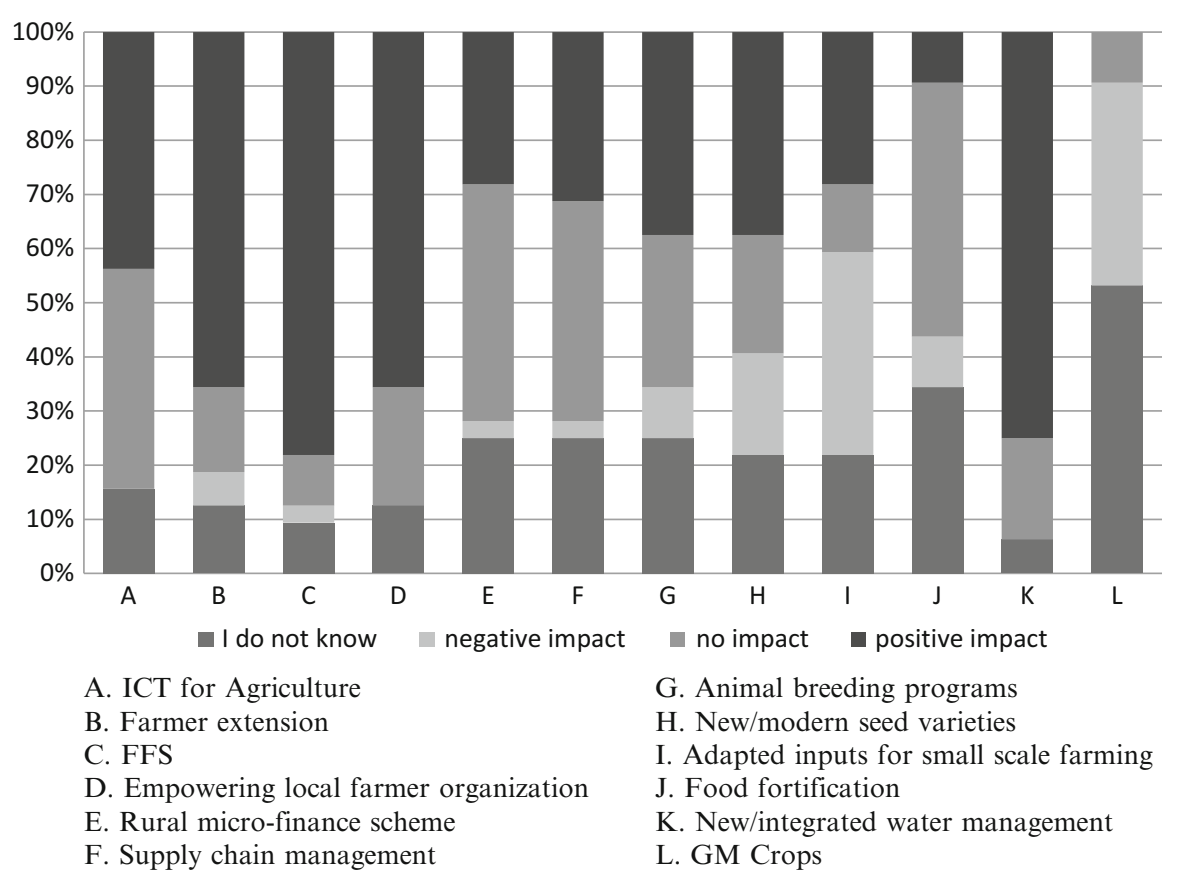

Fig. A2 In your opinion, are the following types of innovation likely to be environmentally friendly? (Source: Authors' compilation based on survey) 


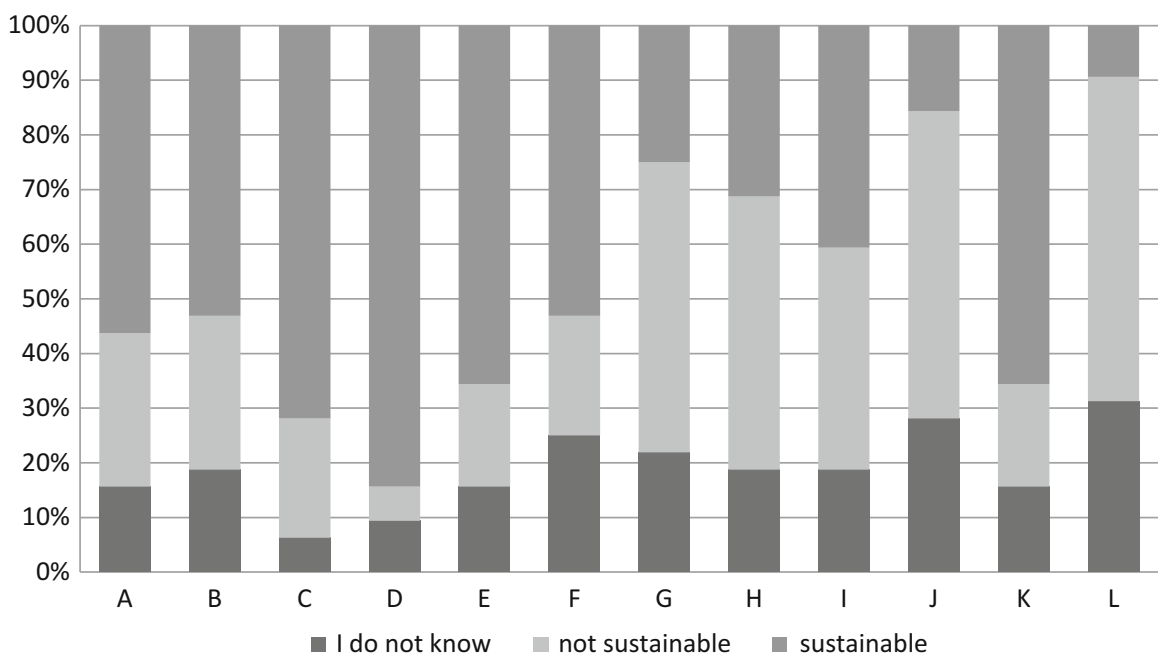

Fig. A3 In your opinion, are the following types of innovation economically sustainable (i.e., under market conditions, without the help of donor/public money) over the longer term, beyond the first implementation program?

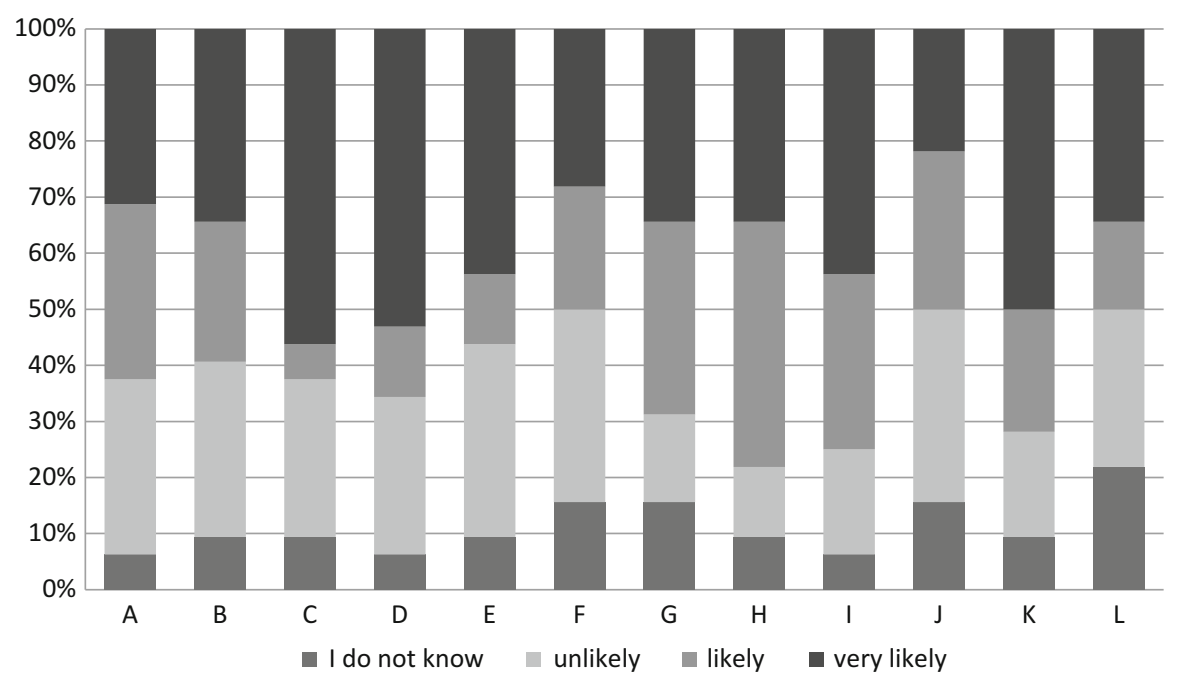
A. ICT for Agriculture
B. Farmer extension
C. FFS
D. Empowering local farmer organization
E. Rural micro-finance scheme
F. Supply chain management

G. Animal breeding programs

H. New/modern seed varieties

I. Adapted inputs for small scale farming

J. Food fortification

K. New/integrated water management

L. GM Crops

Fig. A4 Do you foresee trade-offs between environmental, social, and/or economic impacts in the following types of innovation? (Source: Authors' compilation based on survey) 


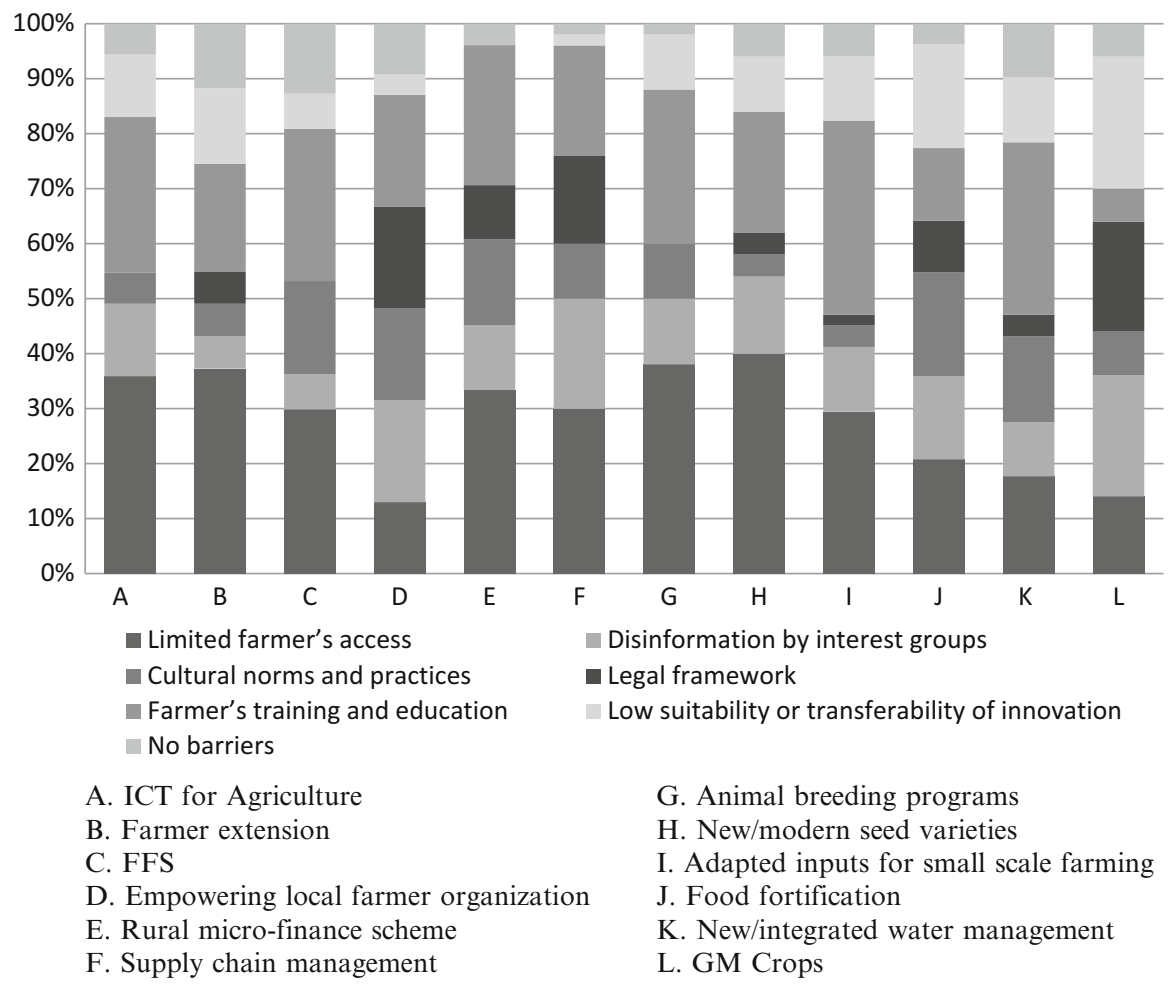

Fig. A5 Please state, in your opinion, up to two of the main barriers to fostering innovation in each of the following areas (Source: Authors' compilation based on survey)

\section{References}

Aker JC (2011) Dial "A" for agriculture: a review of information and communication technologies for agricultural extension in developing countries. Agric Econ 42(6):631-647. doi:10.1111/j. 1574-0862.2011.00545.x

Aker JC, Mbiti IM (2010) Mobile phones and economic development in Africa. Working paper No 211. Center for Global Development, Washington, DC

Arifin HS, Munandar A, SchultinK G, Kaswanto RL (2012) The role and impacts of small-scale, homestead agro-forestry systems ("pekarangan") on household prosperity: an analysis of agroecological zones of Java, Indonesia. Int J AgriSci 2(10):896-914

Australian Custard Apple Growers Association (ACAGA) (2011) http://www.custardapple.com. au/index.php?option $=$ com_content\&view $=$ article\&id $=48 \& I t e m i d=55$. Accessed 10 May 2014

Beyer P (2010) Golden rice and "golden" crops for human nutrition. N Biotechnol 27(5):478-481. doi:10.1016/j.nbt.2010.05.010 
Black RE, Allen LH, Bhutta ZA, Caulfield LE, de Onis M, Ezzati M, Mathers C, Rivera J (2008) Maternal and child undernutrition: global and regional exposures and health consequences. Lancet 371(9608):243-260. doi:10.1016/S0140-6736(07)61690-0

Bouis HE, Hotz C, McClafferty B, Meenakshi JV, Pfeiffer WH (2011) Biofortification: a new tool to reduce micronutrient malnutrition. Food Nutr Bull 32(1):31-40

Braun A, Duveskog D (2008) The farmer field school approach - history, global assessment and success stories, background paper for the IFAD Rural Poverty Report 2011. International Fund for Agricultural Development, Rome

Braun A, Jiggins J, Röling N, van den Berg H, Snijders P (2006) A global survey and review of farmer field school experiences, Report prepared for the International Livestock Research Institute. Endelea, Wageningen

Cabalda AB, Rayco-Solon P, Solon JAA, Solon FS (2011) Home gardening is associated with Filipino preschool children's dietary diversity. J Am Diet Assoc 111(5):711-715. doi:10.1016/ j.jada.2011.02.005

Conway G, Waage J (2010) Science and innovation for development. Collaborative on Development Science, London

Dockes A, Tisenkopfs T, Bock B (2011) Reflection paper on AKIS, Collaborative Working Group Agricultural Knowledge and Innovation Systems, WP 1. Available at: http://ec.europa.eu/ research/agriculture/scar/pdf/akis-wp1-final.pdf. Accessed 13 Jan 2013

Donner J (2009) Mobile-based livelihood services in Africa: pilots and early deployments. In: Fernandez-Ardevol M, Hijar AR (eds) Communication technologies in Latin America and Africa: a multidisciplinary perspective. Internet Interdisciplinary Institute (IN3), Barcelona

Fafchamps M, Minten B (2012) Impact of SMS-based agricultural information on Indian farmers. World Bank Econ Rev 26(3):383-414. doi:10.1093/wber/lhr056

FAO (2006) The double burden of malnutrition: case studies from six developing countries. Food and Agriculture Organization of the United Nations, Rome

FAO, IFAD, WFP (2013) The state of food insecurity in the world 2013. The multiple dimensions of food security. Food and Agriculture Organization of the United Nations, Rome

Galluzzi G, Eyzaguirre P, Negri V (2010) Home gardens: neglected hotspots of agro-biodiversity and cultural diversity. Biodivers Conserv 19(13):3635-3654. doi:10.1007/s10531-010-9919-5

Gómez MI, Barrett CB, Raney T, Pinstrup-Andersen P, Meerman J, Croppenstedt A, Carisma B, Thompson B (2013) Post-green revolution food systems and the triple burden of malnutrition. Food Policy 42:129-138. doi:10.1016/j.foodpol.2013.06.009

Goyal A (2010) Information, direct access to farmers, and rural market performance in central India. Am Econ J 2(3):22-45. doi:10.1257/app.2.3.22

Hanstad T, Brown J, Prosterman R (2002) Larger homestead plots as land reform? International experience and analysis from Karnataka. Econ Polit Wkly 37(29):3053-3062

Hargrave TJ, van De AH (2006) A collective action model of institutional innovation. Acad Manage Rev 31(4):864-888. doi:10.5465/AMR.2006.22527458

Hawkes C, Eckhardt C, Ruel M, Minot N (2005) Diet quality poverty, and food policy: a new research agenda for obesity prevention in developing countries. SCN News 29:20-22

Hierli U, Polak P (2000) Poverty alleviation as a business. Swiss Agency for Development and Cooperation, Bern

Hughes J d'A, Keatinge JDH (2011) The Nourished Millenium: how vegetables put global goals for healthy, balanced diets within reach. In: Holmer R, Linwattana G, Nath P, Keatinge JDH (eds) High value vegetables in southeast Asia: production, supply, and demand, Proceeding SEAVEG 2012. Available at: http://203.64.245.61/fulltext_pdf/EB/2011-2015/eb0197.pdf. Accessed 20 Jan 2012

IAASTD (2009) Agriculture at a crossroads: synthesis report - international assessment of agricultural knowledge, science and technology for development. Island Press, Washington, DC

IFAD (2007) Innovation strategy. International Fund for Agricultural Development, Rome 
Institute of Nutrition, Mahidol University (2014) ASEAN food composition database, electronic version 1, Thaliand. Available at http://www.inmu.mahidol.ac.th/aseanfoods/composition data.html. Accessed 10 June 2014

ITU (2011) The world in 2011: ICT facts and figures. International Telecommunication Union, Geneva

Jensen R (2007) The digital provide: information (technology), market performance, and welfare in the South Indian fisheries sector. Q J Econ 122(3):879-924. doi:10.1162/qjec.122.3.879

Juma C, Yee-Cheong L (2005) Innovation: applying knowledge in development, UN Millennium Project, Task Force on Science, Technology, and Innovation. Earthscan, London

Kay M, Brabben T (2000) Treadle Pumps for irrigation in Africa, Knowledge synthesis report 1, International Program for Technology and Research in Irrigation and Drainage, Rome

Kehlenbeck K, Arifin H, Maass B (2007) Plant diversity in homegardens in a socio-economic and agro-ecological context. In: Tscharntke T, Leuschner C, Zeller M, Guhardja E, Bidin A (eds) Stability of tropical rainforest margins. Springer, Berlin/Heidelberg, pp 295-317

Labonne J, Chase RS (2009) The power of information: the impact of mobile phones on farmer's welfare in the Philippines. Policy research working paper No 4996. World Bank, Washington, DC

Lim TK (1996) Durian 1. Characteristics and cultivars. Agnote 639 No. D29, Available at http:// www.nt.gov.au/d/Primary_Industry/Content/File/horticulture/639.pdf. Accessed 10 May 2014

Lin LI, Hsiao YY, Kuo CG (2009) Discovering indigenous treasures: promising indigenous vegetables from around the world. AVRDC - The World Vegetable Center Publication No 09-720. AVRDC - The World Vegetable Center, Shanhua, Taiwan

Lozoff B, Smith JB, Kaciroti N, Clark KM, Guevara S, Jimenez E (2013) Functional significance of early-life iron deficiency: outcomes at 25 years. J Pediatr 163(5):1260-1266. doi:10.1016/j. jpeds.2013.05.015

Martorell R (1999) The nature of child malnutrition and its long-term implications. Food Nutr Bull 20(3):288-292

Masset E, Haddad L, Cornelius A, Isaza-Castro J (2012) Effectiveness of agricultural interventions that aim to improve nutritional status of children: systematic review. BMJ 344:d8222. doi:10. 1136/bmj.d8222

Meenakshi JV, Johnson NL, Manyong VM, DeGroote H, Javelosa J, Yanggen DR, Naher F, Gonzalez C, García J, Meng E (2010) How cost-effective is biofortification in combating micronutrient malnutrition? An ex ante assessment. World Dev 38(1):64-75. doi:10.1016/j. worlddev.2009.03.014

Meyer R (2010) Low-input intensification in agriculture: chances for small-scale farmers in developing countries. GAIA - Ecol Perspect Sci Soc 19(4):263-268

Mitchell R, Hanstad T (2004) Small homegarden plots and sustainable livelihoods for the poor. LSP working paper 11. Food and Agriculture Organization of the United Nations, Rome

Morton J (1987) Fruits of warm climates. Morton JF, Miami

Muthayya S, Rah JH, Sugimoto JD, Roos FF, Kraemer K, Black RE (2013) The global hidden hunger indices and maps: an advocacy tool for action. PLoS One 8(6):e67860. doi:10.1371/ journal.pone.0067860

Namara RE, Hanjra MA, Castillo GE, Ravnborg HM, Smith L, van Koppen B (2010) Agricultural water management and poverty linkages. Agric Water Manag 97(4):520-527. doi:10.1016/j. agwat.2009.05.007

Nestel P, Bouis HE, Meenakshi JV, Pfeiffer W (2006) Biofortification of staple food crops. J Nutr 136(4):1064-1067

Pampolino MF, Witt C, Pasuquin JM, Johnston A, Fisher MJ (2012) Development approach and evaluation of the nutrient expert software for nutrient management in cereal crops. Comput Electron Agric 88:103-110. doi:10.1016/j.compag.2012.07.007

Polak P, Adhikari D, Nanes B, Salter D (2003) Transforming rural water access into profitable business opportunities. In: Butterworth J, Moriarty P, van Koppen B (eds) Water, poverty and the productive uses of water at the household level, proceeding of an international symposium, Johannesburg 
Popkin BM, Adair LS, Ng SW (2012) Global nutrition transition and the pandemic of obesity in developing countries. Nutr Rev 70(1):3-21. doi:10.1111/j.1753-4887.2011.00456.x

Qiang CZ-W, Kuek SC, Dymond A, Esselaar S (2011) Mobile applications for agriculture and rural development. World Bank, Washington, DC

Ruttan VW, Hayami Y (1984) Toward a theory of induced institutional innovation. J Dev Stud 20 (4):203-223. doi:10.1080/00220388408421914

Shetty P (2012) Public health: India's diabetes time bomb. Nature 485(7398):S14-S16

Soemarwoto O, Soemarwoto I, Karyono, Soekartadireja EM, Ramlan A (1975) The Javanese home garden as an integrated agro-ecosystem. In: Proceeding of an international congress on the human environment, science council of Japan, Kyoto, Available at http://archive.unu.edu/ unupress/food/8F073e/8F073E08.htm. Accessed 7 Jan 2013

Soemarwoto O, Soemarwoto I, Karyono, Soekartadireja EM, Ramlan A (1985) The Javanese home garden as an integrated agro-ecosystem. Food Nutr Bull 7(3):44.47

Stadlmayr B, Charrondiere UR, Addy P, Samb B, Enujiugha VN, Bayili RG, Fagbohoun EG, Smith IF, Thiam I, Burlingame B (2010) Composition of selected foods from West Africa. Food and Agriculture Organization of the United Nations, Rome

Stoler A (1978) Garden use and household economy in rural Java. Bull Indones Econ Stud 14(2):85-101. doi:10.1080/00074917812331333331

Swinnen J (2011) The right price of food. Dev Policy Rev 29(6):667-688. doi:10.1111/j.14677679.2011.00552.x

Uphoff N, Kassam A (2008) The System of Rice Intensification (SRI), STOA project agricultural technologies for developing countries paper. Food and Agriculture Organization of the United Nations, Rome

Victora CG, Adair L, Fall C, Hallal PC, Martorell R, Richter L, Sachdev HS (2008) Maternal and child undernutrition: consequences for adult health and human capital. Lancet 371 (9609):340-357. doi:10.1016/S0140-6736(07)61692-4

Vodafone Group and Accenture (2011) Connected agriculture: the role of mobile in the food and agriculture value chain, Available at: http://www.vodafone.com/content/dam/vodafone/about/ sustainability/2011/pdf/connected_agriculture.pdf. Accessed 10 Feb 2013

von Braun J, Tadesse G (2012) Global food price volatility and spikes: an overview of costs, causes, and solutions. ZEF discussion papers on development policy No 161. Center for Development Research, Bonn

Webb P (2010) Medium - to long-run implications of high food prices for global nutrition. J Nutr 140(1):143S-147S. doi:10.3945/jn.109.110536

Webb P (2013) Impact pathways from agricultural research to improved nutrition and health: literature analysis and research priorities. http://www.fao.org/fileadmin/user_upload/agn/pdf/ Webb_FAO_paper_Webb_June_26_2013_.pdf. Accessed 10 Oct 2013

Woodhill J (2010) Capacities for institutional innovation: a complexity perspective. IDS Bull 41 (3):47-59. doi:10.1111/j.1759-5436.2010.00136.x

World Bank (2002) World development report 2002: building institutions for markets. World Bank, Washington, DC

World Bank (2008) World development report 2008: agriculture for development. World Bank, Washington, DC

World Bank (2011) ICT in agriculture: connecting smallholders to knowledge, networks, and institutions. World Bank, Washington, DC

Yang RY, Keding GB (2009) Nutritional contributions of important African Indigenous vegetables. In: Shackleton CM, Pasquini M, Drescher AW (eds) African indigenous vegetables in Urban agriculture. Earthscan, Virginia 